\title{
Optimization of Furniture Configuration for Residential Living Room Spaces in Quality Elderly Care Communities of Macao
}

XIAOXIAO WANG ( $\nabla$ sIswa@hotmail.com)

Macau University of Science and Technology https://orcid.org/0000-0002-8988-947X

Ruiting Shi

City University of Macau

Fangru Niu

Macau University of Science and Technology

Siyang Liang

Affiliated High School of South China Normal University

\section{Research Article}

Keywords: Macau, Aged people, Ergonomics, Furniture configuration

Posted Date: June 23rd, 2021

DOI: https://doi.org/10.21203/rs.3.rs-621344/v1

License: (c) (i) This work is licensed under a Creative Commons Attribution 4.0 International License. Read Full License

Version of Record: A version of this preprint was published at Frontiers of Architectural Research on December 1st, 2021. See the published version at https://doi.org/10.1016/j.foar.2021.11.002. 


\begin{abstract}
Living conditions in Macao are characterized by dense population, land shortage, and old residences, especially on the Macao Peninsula. This paper explores the demands and living conditions of different types of aged residents of the Youhan Community of Macau by questionnaire survey and research analysis. The demands and living conditions are then classified and summarized through quantitative analysis, and their correlations are identified. Based on ergonomics and the physical, psychological, and behavioral habits of aged people, issues are identified that require attention when configuring furniture for different types of aged people in their residential living spaces. Finally, by combining the demands of different types of aged people with the issues that need attention, several criteria on interior furniture configuration are proposed for different types of aged people. This paper presents a preliminarily quantifiable model for living room furniture configuration from the perspective of aged people.
\end{abstract}

\title{
1 Introduction
}

According to assumptions and forecasts based on the demographic statistics of Macao, the aged population of Macao will grow at a faster rate than the working-age population ${ }^{[1]}$. Furthermore, there is a lack of unified standards on the services provided by the Macau government to aged people, who are collectively classified as a vulnerable group in need of special care. This one-size-fits-all approach has led to repetitive or unsuitable services. In addition to governmental organizations, many non-governmental organizations are also providing services for aged people. Obviously, the differences in the services received by aged people from different service centers are significant. In addition, because of time-consuming negotiations between various governmental organizations as well as between governmental and non-governmental organizations, many aged people in need of help have to stay at home or wait for a long time ${ }^{[1]}$. This explains why most aged people can only rely on home care.

Currently, elderly care spaces in China stress the uniformity of decoration, furniture, and style; however, how to truly associate specific furniture configurations and types with different users has not been explored to date. That is, visual comfort in the design of these elderly care spaces has been preliminarily explored $^{[2]}$, but no clear referential criteria have been established on interior furniture configuration for elderly residences. Commonly, living rooms are open spaces with diversified functions in the residential environment. With increasing age, aged people experience changes in their physical, psychological, and behavioral habits, and encounter more obstacles in their daily life ${ }^{[3]}$; therefore, their demands are very different from the demands of other age groups. At present, the Chinese elderly care system still needs to be improved, and the acceptance of nursing homes for the elderly across society is still low. Thus, except for special circumstances, the natural choice of most aged people still remains home care, which is why targeted furniture configuration is particularly important.

By investigating the interior spaces of communities of the elderly and the living conditions of aged people in Macao, this paper first classifies aged people in Macao into different types, and identifies their personal conditions, preferences, and demands. Next, ergonomics for the control of furniture size is introduced. Finally, several relevant criteria on interior furniture configuration are put forward that are applicable to different types of aged people based on the weights of furniture features assigned by them. The findings of this paper offer a reference about interior furniture configuration for different types of aged people.

\section{Characteristics And Demands Of Aged People 2.1 Definition and classification of aged people}

The United Nations (UN) has established the following criteria for the classification of aged people: (1) People aged between 65 and 75 are young aged people, who experience a gradual decline of physical functions which, however, does not affect their life or working competence. (2) People aged between 75 and 85 are old aged people, who go through a continuous decline of physical functions and reduction of response speed. Furniture configuration for this group should be capable to compensate for their declining competence, and meet their increased demands with regard to accessibility, materials, and convenience. Aged people in this age group also constantly feel a sense of loneliness; therefore, communication spaces are also indispensable. (3) People aged above 85 are classified as longevous aged people, who are in need of continuous personal care because of their generally poor physical functions (auditory, visual, and sensory functions).

According to the Chinese Codefor design of residential building for the aged, aged people, depending on their health status, can be classified into self-helping aged people, device-helping aged people, and under-nursing aged people. (1) Self-helping aged people have sound physical health, and can take care of themselves in daily life, so they mostly choose home care. (2) Device-helping aged people have to rely on devices such as armrests, walking sticks, wheelchairs, and lifting facilities to take care of themselves. If choosing home care, they depend heavily on auxiliary devices. (3) Under-nursing aged people need long-term care or professional medical help from others in their daily life, as they are incapable of taking care of themselves. The recommended care mode for them is institutional care.

\subsection{Psychological Characteristics And Demands Of Aged People}

\section{(1) Sensory function}

Eyesight: After reaching the age of 50, most people begin to experience diminutions of eyesight, including presbyopia, senile cataract, declining eye adaptability, as well as reduced ability to distinguish between images or colors. Specifically, the ability to distinguish between colors declines to $76 \%$ in people aged between 60 and 70, and to 56\% in people aged between 80 and 90 . 
Hearing: Tinnitus and dull hearing symptoms gradually emerge as people age. Hearing loss in aged people not only directly affects their speech perception ability, thus causing difficulties in daily communication, but may also induce grumpiness, bigotry, somnolence, tinnitus, and dizziness.

Smell, taste, and touch: Ageing also induces a gradual decline in the sense of smell and taste of aged people ${ }^{[4]}$. For instance, skin touch declines noticeably in people aged above $60^{[5]}$

(2) Motor system

Reduced limb flexibility: Aged people usually have a lower body height, poorer limb flexibility, more fat mass, and less muscle mass ${ }^{[6]}$. As a result of the degeneration of motor nerves and atrophic tendons, ligaments, and other body parts, they also experience a decline in their limb flexibility and body control, and become susceptible to diseases such as scapulohumeral periarthritis and arthritis ${ }^{[7]}$.

Reduced muscular strength: The declining muscular strength and elasticity lead to muscular atrophy in aged people. In addition, fatigability and poor endurance also pose difficulties to aged people who engage in physical labor, long-term motion, standing, and carrying activities ${ }^{[8]}$. For this reason, furniture configuration for aged people should avoid soft sofas and beds, as soft sofas and beds not only cause cervical and back pains but also pose difficulties in getting up and exerting force.

\subsection{Psychological Characteristics And Demands Of Aged People}

As they age, aged people undergo a decline of mobility, self-helping ability, and physical functions, which poses barriers for most, both physically and mentally.

(1) Sense of loneliness

Having to stay at home for long hours because of advanced age and physical inconveniences, aged people cannot freely arrange their life, and tend to feel empty and lonely. Dayinanddayout, they feel abandoned, and are more likely to place their hopes on their children, grandchildren, spouses, or friends, wishing for their love in return. In this case, it is highly necessary to provide comfortable communication spaces as part of the furniture layout.

(2) Sense of loss

The sense of loss is especially strong in retired aged people. This is because retirement results in longer stays at home, less social contacts, reduced responsibilities and burdens, and gradual physical and intellectual declines, all of which cause strong psychological impacts. With the fading of the "sense of achievement" formed in long-term collective work and life, they often sense that they have been disconnected from society, and have become irrelevant to others.

(3) Sense of depression

Moods constitute a key factor of physical health. Over the past few years, with the state of depression being increasingly prevalent, depression in aged people has also begun to receive due consideration. Aged people are susceptible to mood swings, and can easily become self-abased, emotional, sensitive, suspicious, or stubborn. After retirement, they may become idle and unoccupied, and their physical inconveniences become more prominent, often making them feel frustrated and depressed.

(4) Sense of insecurity

The decline of physical functions often induces a sense of insecurity in aged people. In such a case, the interior furniture configuration should be fully utilized to create accessibility and conveniences for them, as well as improve their sense of security. It has been suggested that lightweight furniture with warm colors should be selected to make convenience for movement and offer warm feelings.

(5) Sense of neighborhood

Communication with others not only reduces the senses of loneliness, loss, and depression aged people often experience, but also makes them feel confident and respected. In this sense, furniture in the living room should be easy to move, and sufficient space for visits and socializing needs to be reserved.

(6) Sense of comfort

Interior layout and furniture configuration should target the specific demands of different types of aged people, fit their physical conditions, assist them in daily life, and create convenient spaces for them to relax and rest.

\subsection{Effect Of Aged People's Life Behaviors On Furniture Configuration}

Environmental behavioral science explores environmental designs that suit people's life, production, and learning. Such knowledge helps designers to identify problems that require attention in the recreation of artificial environments, and assists people in leveraging environmental factors to achieve their goals ${ }^{[9]}$. Environmental behavioral science can also be employed to guide interior furniture configuration for aged people, i.e., identify the kinds of furniture configuration that suit the life and meet the living demands of aged people. 
(1) Self-helping aged people

Self-helping aged people can take care of themselves, so they mostly choose home care. When they go for a trip, they return with photos and souvenirs. They also tend to keep all certificates and trophies they have won from work. Aged people of this type, need spaces in the living room to exhibit their "great memories" and "moments of glory" to visiting colleagues, neighbors, friends, and relatives. However, no person can always stay independent; therefore, furniture configuration for self-helping aged people should not focus solely on their work and life demands at the current stage, but should also reserve space for their future life $\mathrm{e}^{[10]}$.

(2) Device-helping aged people

Device-helping aged people account for as much as $47 \%$ of the total population of aged people. Given that device-helping aged people have difficulty with walking and getting about, for them, furniture configuration should aim to meet all their daily demands, and help them to move freely at home. Aged people at this stage have shifted the focus of their life to themselves, so their furniture should offer assistance, conveniences, and security, and help them prevent accidents and perform necessary activities.

Device-helping aged people spend most of their time at home, chatting with friends and families. For them, it is important to reserve space in the living room, where they can sit and chat with visitors. The chairs in the living room should be easy to move, and convenient to arrange.

(3) Under-nursing aged people

The physical functions of under-nursing aged people have declined to the extent that they can no longer take care of themselves and must therefore rely on family members or nursing workers for life activities (limited to eating, sleeping, washing, and entertainment). Some of them are permanently bed-ridden, and rely on family members or nursing workers to complete even the most basic activities. Considering that their demands for furniture are not as relevant at this stage, this paper mainly discusses the demands of nursing workers. In the triangle relationship among under-nursing aged people, furniture, and nursing workers, furniture assists nursing workers in taking care of aged people, improves the life of aged people, and contributes to the work of nursing workers. However, the life demands of under-nursing aged people must not be neglected.

\section{Strategies Of Furniture Configuration}

As a main element of interior spaces, furniture offers dominant colors and plays a vital role in such spaces. The control of furniture quantity and the selection of furniture style directly determine the comfort of an interior space. In general, the most suitable furniture quantity of an interior space is $35-40 \%$ of the total area. The plane size and vertical height of furniture also play essential roles in spatial adjustment, so it is necessary to adopt the space scale as benchmark in furniture configuration and obey the spatial volumetric relationship among furniture.

(1) Improvement of living conditions

Reasonable furniture configuration improves living conditions mainly in the following three aspects: First, it enables better use of furniture for serving people in their daily lives. Second, it greatly affects people's daily life and living spaces, i.e., by creating open living spaces for people and strengthening their physical and psychological health. Third, it has the power to change unhealthy living habits, and promotes healthy lifestyles ${ }^{[11]}$.

(2) Harmonious unity

Harmonious unity is mainly embodied in the harmonious unity between furniture and interior spaces. The ultimate goal of harmonious unity is to achieve a visual balance between furniture and interior spaces, and yield aesthetic enjoyment ${ }^{[12]}$. Unity should also be achieved between furniture and the interior layout to give the visual impression of balance in size. In addition to accommodating the preferences of the owner, furniture configuration is also supposed to weigh the pros and cons, and achieve consistency in style, shape, color, and texture. By drawing a clear distinction between what is primary and what is secondary, furniture configuration aims to enhance the senses of space and depth, strengthen the sense of security, and create harmonious and unified interior spaces.

(3) Flexibility

Furniture configuration for interior spaces is highly flexible. Depending on personal demands and preferences, furniture configuration should maximize flexibility. Different furniture combinations create different feelings for interior spaces. Moreover, flexible furniture configuration achieves the effect of spatial division, and creates new spiritual experiences by adjusting spatial functions and atmosphere.

(4) Comfort

Comfort is a subjective feeling closely related to personal traits. In interior furniture configuration, comfort is mainly embodied in the relationships of furniture with spaces, instead of being confined to a specific piece or type of furniture. Thus, research on the comfort of furniture configuration focuses on the relationships between furniture and people, as well as between furniture and interior spaces.

(5) Scientific layout

Furniture configuration consists of two parts, i.e., the furniture itself and furniture layout. With regard to furniture configuration for a space, the first step is to determine the functions of the space based on intended human behaviors and activities, and then, configuring suitable furniture to realize these functions. The 
aim is to arrange suitable furniture at suitable positions in a scientific and reasonable manner according to the size and location of living room spaces and the physical and psychological characteristics of the resident.

(6) Aesthetics

Judging from the perspective of aesthetics, the shape and style of furniture should match the style of interior decorations. Furniture can objectively reflect material and spiritual functions, and play extremely vital roles in the coordination and creation of interior spaces. By reshaping spatial forms, furniture identifies, molds, and optimizes spaces, and enriches spatial contents at deeper levels.

\section{Survey Analysis Of The Youhan Community In Macao 4.1 Status of the Youhan Community}

Youhan Community was transformed into a residential quarter from 1980 to 1990,andis now referred to as "Youhan New Village". Because of the inrush of many new settlers with low educational level, this area remained relatively underdeveloped. Driven by recent developments, Youhan Community has witnessed the emergence of many amenities, and has become a densely populated area of Macao. However, as a very old community, it faces a series of life-related problems, such as old buildings, ageing population, and shabby interior spaces. According to a census on AreiaPreta and Youhan Community conducted by the Statistics and Census Service of Macao in mid-2016, people aged above 55 accounted for $26 \%$ of the total population (Fig. 3).

\subsection{Overview Of The Questionnaire Survey}

\subsubsection{Methods and limitations of the questionnaire survey}

(1) Methods

The questionnaire was prepared in advance. Considering that the majority of aged people cannot see clearly or use electronic devices correctly, the questionnaire survey was conducted in the form of interviews. That is, experimenters asked the questions, and then filled the questionnaire with their answers. Parts of the respondents were very kind, and invited us into their home for video shooting. They also informed us of the living room spaces available for shooting. The questionnaire was filled with their answers later.

(2) Limitations

Considering the inconvenience associated with having a stranger invited by aged people into their homes in Macao, especially into bedrooms and other private spaces, living room spaces were mainly investigated in the questionnaire survey. The survey was conducted in person in the community, and the respondents were predominantly aged people who could go outside. To obtain data on aged people who had to stay at home for long hours, others were interviewed to obtain information about their demands and their residential living room spaces.

\subsubsection{Basic Information Of Respondents}

The survey retrieved a total of 143 questionnaires, 130 of which were valid. The respondents were aged between 51 and 90 , with a gender ratio of $78 / 22 \%$ (male/female). To be specific, the age group of 51-65 accounted for the largest proportion (49\%), followed in succession by the age groups of $65-75$ (37\%), 75-85 (9\%), and $\geq 85$ (5\%). In terms of their educational level, $57 \%$ had primary school diploma or below, while those with junior high school diploma, senior high school diploma, and college degree accounted for $31 \%, 8 \%$, and $4 \%$, respectively. Furthermore, $11 \%$ of the surveyed respondents lived alone, $21 \%$ received care by a nursing worker, $24 \%$ lived with their children, and $45 \%$ lived with their spouse (see Fig. 4 ).

\subsection{Questionnaire Survey Results And Analysis}

According to the UN criteria on the classification of aged people, male and female respondents were each classified into four age groups $(\leq 65,65-75,75-85$, and $\geq 85$ ), and analyzed by age groups and gender. The major factors of furniture configuration summarized above were adopted to explore their demands.

\subsubsection{Living Conditions Of Aged People}

Male and female respondents aged $\leq 65$ could basically take care of themselves. $30 \%$ of male respondents and $13.12 \%$ of female respondents received care by their spouse. Few received care by their children. This suggests that aged people in this age group, are still in the initial stage of decline, are physically healthy, and do not need too much care from others.

Most of male and female respondents aged 65-75, especially females, could take care of themselves. Starting with this age group, the number of male respondents receiving care by their spouse began to increase. To be specific, $53.45 \%$ of male respondents received care of their spouse, and $30.76 \%$ received intensive care of their spouse. In contrast, $7.14 \%$ of female respondents received care by their spouse. Aged people in this age group begin to experience a gradual decline of physical functions, and some show clear signs of decline or other prominent problems. 
The numbers of male and female respondents capable of taking care of themselves began to decrease as they entered the age group of 75-85, and higher proportions received care by their children. $60 \%$ of male respondents in this age group received care of their spouse, while the figure for female respondents was only $11.11 \%$. Clearly, aged people in this age group, especially males, begin to rely on others for care.

Respondents aged $\geq 85$ showed accelerated degeneration of their physical functions. None of the male respondents could completely take care of themselves, and $75 \%$ of male respondents and $66.3 \%$ of female respondents received care of their children. Few of them received care by their spouse, mainly because spouses themselves were getting older and weaker. Clearly aged people in this age group depend more heavily on their children, instead of on each other.

For males in Macau, the degree of self-cooking is closely related to their age. That is, as people advance in age, they are less likely to take care of themselves and more likely to receive care by others, which results in a lower degree of self-cooking. In contrast, age more significantly affects the daily life of females in Macao. The degree of self-helping is higher in females than in males, and their demand for care is also lower than in males. The degree of self-cooking is directly proportional to the proportion of indoor and outdoor activities and the degree of self-helping.

On the basis of analyzing changes in the degree of self-helping of males and females, this study further probed into what they thought to be their main physical problems and daily activities, with the aim to identify the specific causes of the decline in their degree of self-helping. Based on the results of interview and survey, the main activities of aged people were divided into housework, watching TV, reading books and newspapers, listening to radio, chatting with relatives or friends at home, and other activities (including outdoor activities and outing).

Seen from different age groups (Table 1), the proportion of male aged people doing housework was roughly the same across all age groups. In the two age groups of 65-75 and 75-85, the proportions of male aged people watching TV were obviously lower than those in the other two age groups. The proportions of outing were higher than those in the other two age groups. The proportions of reading books and newspapers, listening to radio, and chatting with relatives or friends at home were lower than those in the other two age groups. In general, people aged 65-75 and those aged 75-85 are in the initial ageing stage and the continuous ageing stage, respectively. They are still relatively healthy, and most do not have to work or rear a child for their children. Some of them go out to maintain their social networks, and fill the voids left by work, social responsibilities, and childrearing to compensate for the sense of emptiness and loss they may feel.

Table 1

Summary of overlapping daily activities between males and females

(Source: Self-drawing)

\begin{tabular}{|c|c|c|c|c|c|c|}
\hline \multirow[t]{2}{*}{ Gender } & \multirow[t]{2}{*}{ Item } & \multicolumn{4}{|l|}{ Age } & \multirow{2}{*}{$\begin{array}{l}\text { Summary }(n= \\
\text { 32) }\end{array}$} \\
\hline & & $\begin{array}{l}65 \text { years and } \\
\text { below }(n=10)\end{array}$ & $\begin{array}{l}65-75 \text { years old }(n \\
=13)\end{array}$ & $\begin{array}{l}75-85 \text { years } \\
\text { old }(n=5)\end{array}$ & $\begin{array}{l}85 \text { years old and } \\
\text { above }(n=4)\end{array}$ & \\
\hline \multirow[t]{9}{*}{ Male } & Housework & $80.00 \%$ & $76.92 \%$ & $80.00 \%$ & $75.00 \%$ & $78.13 \%$ \\
\hline & watch TV & $60.00 \%$ & $38.46 \%$ & $40.00 \%$ & $75.00 \%$ & $50.00 \%$ \\
\hline & Read books and newspapers & $30.00 \%$ & $30.77 \%$ & $40.00 \%$ & $0.00 \%$ & $28.13 \%$ \\
\hline & Listen to the radio & $30.00 \%$ & $23.08 \%$ & $20.00 \%$ & $0.00 \%$ & $21.88 \%$ \\
\hline & $\begin{array}{l}\text { Chat with relatives and friends } \\
\text { at home }\end{array}$ & $40.00 \%$ & $15.38 \%$ & $20.00 \%$ & $50.00 \%$ & $28.13 \%$ \\
\hline & Other & $40.00 \%$ & $61.54 \%$ & $60.00 \%$ & $50.00 \%$ & $53.13 \%$ \\
\hline & \multicolumn{6}{|l|}{ Chi-square test: $\chi^{2}=6.416 p=0.972$} \\
\hline & \multirow[t]{2}{*}{ Item } & Age & & & & \multirow{2}{*}{$\begin{array}{l}\text { Summary }(n= \\
115)\end{array}$} \\
\hline & & $\begin{array}{l}65 \text { years and } \\
\text { below }(n=61)\end{array}$ & $\begin{array}{l}65-75 \text { years } \\
\text { old }(n=42)\end{array}$ & $\begin{array}{l}75-85 \text { years } \\
\text { old }(n=9)\end{array}$ & $\begin{array}{l}85 \text { years old and } \\
\text { above }(n=3)\end{array}$ & \\
\hline \multirow[t]{7}{*}{ Female } & Housework & $90.16 \%$ & $97.62 \%$ & $100.00 \%$ & $100.00 \%$ & $93.91 \%$ \\
\hline & watch TV & $60.66 \%$ & $69.05 \%$ & $77.78 \%$ & $100.00 \%$ & $66.09 \%$ \\
\hline & Read books and newspapers & $49.18 \%$ & $38.10 \%$ & $33.33 \%$ & $33.33 \%$ & $43.48 \%$ \\
\hline & Listen to the radio & $29.51 \%$ & $33.33 \%$ & $11.11 \%$ & $66.67 \%$ & $30.43 \%$ \\
\hline & $\begin{array}{l}\text { Chat with relatives and friends } \\
\text { at home }\end{array}$ & $31.15 \%$ & $50.00 \%$ & $55.56 \%$ & $33.33 \%$ & $40.00 \%$ \\
\hline & Other & $34.43 \%$ & $40.48 \%$ & $33.33 \%$ & $66.67 \%$ & $37.39 \%$ \\
\hline & \multicolumn{6}{|l|}{ Chi-square test: $\chi^{2}=6.525 p=0.970$} \\
\hline
\end{tabular}

In contrast, higher proportions of female aged people in Macau chose to do housework or watch TV. To be specific, the proportion of females doing housework was far higher than that of males, and remained basically the same across different age groups. This suggests that females who are capable of taking care of themselves mostly choose to do housework. This is correlated with the degree of self-helping and the degree of being cared for by others on part of females. The proportions of watching TV increased with age. The proportions of chatting with relatives or friends at home in the age groups of $65-75$ and $75-85$ were 
higher than those in the other two age groups. Generally, the proportions of chatting with relatives or friends at home directly affect the use of communication spaces in the living room. Furniture configuration for audio-video and communication spaces is particularly important for female aged people. In addition to a suitable distance, it is also necessary to consider the number of persons to be accommodated, and the convenience and flexibility of seats.

\subsubsection{Physical Changes And Problems In Aged People}

Physical changes and problems in aged people were analyzed by nine items based on related statistics.

On the whole (see Table 2), the main physical changes observed in male aged people in Macao were poor eyesight, forgetfulness, and weak waist. In contrast, the main physical changes in female aged people included cervical pain, poor eyesight, forgetfulness, and weak waist. A comparison showed that females experienced more obvious physical changes than males in the items both genders have in common.

Table 2

ANOVA of physical changes by gender

(Source: Self-drawing)

\begin{tabular}{|c|c|c|c|c|c|c|c|c|c|c|c|}
\hline \multirow[t]{2}{*}{ Gender } & & \multicolumn{8}{|c|}{ Age(Mean \pm standard deviation) } & \multirow[t]{2}{*}{$F$} & \multirow[t]{2}{*}{$p$} \\
\hline & & \multicolumn{2}{|c|}{$\begin{array}{l}65 \text { years and below }(n= \\
61)\end{array}$} & \multicolumn{2}{|c|}{$\begin{array}{l}65-75 \text { years old }(n \\
=13)\end{array}$} & \multicolumn{2}{|c|}{$\begin{array}{l}75-85 \text { years old }(n= \\
5)\end{array}$} & \multicolumn{2}{|l|}{$\begin{array}{l}85 \text { years old and } \\
\text { above }(n=4)\end{array}$} & & \\
\hline \multirow[t]{13}{*}{ Male } & Similar & \multicolumn{2}{|c|}{$0.60 \pm 0.52$} & \multicolumn{2}{|l|}{$0.38 \pm 0.51$} & \multicolumn{2}{|l|}{$0.00 \pm 0.00$} & \multicolumn{2}{|l|}{$0.00 \pm 0.00$} & 2.968 & $0.049 *$ \\
\hline & Bad eyesight & \multicolumn{2}{|c|}{$0.50 \pm 0.53$} & \multicolumn{2}{|l|}{$0.54 \pm 0.52$} & \multicolumn{2}{|l|}{$0.80 \pm 0.45$} & \multicolumn{2}{|l|}{$0.50 \pm 0.58$} & 0.427 & 0.735 \\
\hline & $\begin{array}{l}\text { Deterioration of } \\
\text { ears }\end{array}$ & \multicolumn{2}{|c|}{$0.00 \pm 0.00$} & \multicolumn{2}{|l|}{$0.15 \pm 0.38$} & \multicolumn{2}{|l|}{$0.40 \pm 0.55$} & \multicolumn{2}{|l|}{$0.00 \pm 0.00$} & 1.961 & 0.143 \\
\hline & Easy to forget & \multicolumn{2}{|c|}{$0.50 \pm 0.53$} & \multicolumn{2}{|l|}{$0.23 \pm 0.44$} & \multicolumn{2}{|l|}{$0.60 \pm 0.55$} & \multicolumn{2}{|l|}{$0.25 \pm 0.50$} & 1.025 & 0.396 \\
\hline & $\begin{array}{l}\text { Hand weakness } \\
\text { or instability }\end{array}$ & \multicolumn{2}{|c|}{$0.10 \pm 0.32$} & \multicolumn{2}{|l|}{$0.00 \pm 0.00$} & \multicolumn{2}{|l|}{$0.20 \pm 0.45$} & \multicolumn{2}{|l|}{$0.25 \pm 0.50$} & 1.024 & 0.397 \\
\hline & $\begin{array}{l}\text { Bad cervical } \\
\text { spine }\end{array}$ & \multicolumn{2}{|c|}{$0.10 \pm 0.32$} & $0.15 \pm 0.38$ & & $0.40 \pm 0.55$ & & $0.25 \pm 0.50$ & & 0.684 & 0.570 \\
\hline & Poor waist & 0.20 & & $0.31 \pm 0.48$ & & $1.00 \pm 0.00$ & & $0.25 \pm 0.50$ & & 4.341 & $0.012^{\star}$ \\
\hline & Inconvenience & 0.10 & & $0.15 \pm 0.38$ & & $0.80 \pm 0.45$ & & $0.25 \pm 0.50$ & & 4.186 & $0.014^{\star}$ \\
\hline & $\begin{array}{l}\text { General } \\
\text { inconvenience }\end{array}$ & 0.10 & & $0.00 \pm 0.00$ & & $0.00 \pm 0.00$ & & $0.25 \pm 0.50$ & & 1.273 & 0.303 \\
\hline & Other changes & 0.30 & & $0.00 \pm 0.00$ & & $0.40 \pm 0.55$ & & $0.25 \pm 0.50$ & & 1.901 & 0.152 \\
\hline & ${ }^{*} p<0.05 * * p<0$ & & & & & & & & & & \\
\hline & & & Age(Mean $\pm s t$ & dard deviatio & & & & & $F$ & & $p$ \\
\hline & & & $\begin{array}{l}65 \text { years and } \\
\text { below }(n=61)\end{array}$ & $\begin{array}{l}65-75 \\
\text { years old }(n \\
=42)\end{array}$ & $\begin{array}{l}75- \\
=9)\end{array}$ & years old $(n$ & $\begin{array}{l}85 \text { yea } \\
\text { above }\end{array}$ & $\begin{array}{l}\text { old and } \\
=3 \text { ) }\end{array}$ & & & \\
\hline Female & Similar & & $0.25 \pm 0.43$ & $0.26 \pm 0.45$ & 0.33 & 0.50 & $0.00 \pm$ & & 0.443 & & 0.723 \\
\hline & Bad eyesight & & $0.79 \pm 0.41$ & $0.67 \pm 0.48$ & 0.56 & 0.53 & $1.00 \pm$ & & 1.458 & & 0.230 \\
\hline & Deterioration of & & $0.18 \pm 0.39$ & $0.29 \pm 0.46$ & 0.33 & 0.50 & $0.67 \pm$ & & 1.695 & & 0.172 \\
\hline & Easy to forget & & $0.66 \pm 0.48$ & $0.60 \pm 0.50$ & 0.67 & 0.50 & $1.00 \pm$ & & 0.705 & & 0.551 \\
\hline & $\begin{array}{l}\text { Hand weakness } \\
\text { instability }\end{array}$ & & $0.05 \pm 0.22$ & $0.07 \pm 0.26$ & 0.00 & 0.00 & $0.33 \pm$ & & 1.579 & & 0.198 \\
\hline & Bad cervical spin & & $0.57 \pm 0.50$ & $0.33 \pm 0.48$ & 0.67 & 0.50 & $0.67 \pm$ & & 2.515 & & 0.062 \\
\hline & Poor waist & & $0.38 \pm 0.49$ & $0.48 \pm 0.51$ & 0.56 & 0.53 & $1.00 \pm$ & & 1.857 & & 0.141 \\
\hline & Inconvenience & & $0.11 \pm 0.32$ & $0.14 \pm 0.35$ & 0.33 & 0.50 & $0.67 \pm$ & & 3.108 & & $0.029 *$ \\
\hline & General inconver & ence & $0.02 \pm 0.13$ & $0.02 \pm 0.15$ & 0.00 & 0.00 & $0.00 \pm$ & & 0.102 & & 0.959 \\
\hline & Other changes & & $0.03 \pm 0.18$ & $0.07 \pm 0.26$ & 0.00 & 0.00 & $0.00 \pm$ & & 0.490 & & 0.690 \\
\hline & $* p<0.05 * * p<0$ & & & & & & & & & & \\
\hline
\end{tabular}

Judging from the age distribution, the proportions of males who experience difficulty in walking and weak waist increased with growing age. Females mainly suffered from difficulty in walking, which affected all respondents aged $\geq 85$. These factors were adopted to analyze the problems with the use of seats. In general, aged people experience a degeneration of motor nerves, and are susceptible to diseases such as scapulohumeral periarthritis, arthritis, and reduced muscular strength. Sometimes, daily activities, such as getting up and standing, can be challenging for them. In this study, the problems with the use of seats 
were divided into difficulty in getting up beside the table, too soft sofas or chairs, difficulty with getting up, uncomfortable chairs, and inconvenience to move or rotate a chair.

With regard to the problems of weak waist and difficulty in walking in male aged people, a model was built for difficulty in getting up beside the table, too soft sofas or chairs, difficulty in standing up, uncomfortable chairs, and inconvenience to move or rotate a chair. Linear regression analysis showed that neither weak waist nor difficulty in walking was reflected in any of these aspects. Generally, males in the age groups of 65-75 and 75-85 prefer outdoor activities and do not use seats very often; therefore, the problems of weak waist and difficulty with walking are usually reflected in walking and outdoor activities.

Females experienced greater difficulty in walking with growing age (see Table 3); therefore, this factor was adopted to judge the demand for use of seats. The model indicated that difficulty in walking could explain $8.5 \%, 14.2 \%$, and $4.9 \%$ of changes in too soft sofas or chairs, difficulty in standing up, inconvenience to move or rotate a chair, and difficulty in getting up beside the table, respectively, suggesting that difficulty in walking exerted significant positive effects on these dependent variables. In contrast, difficulty in walking did not exert any positive effect on uncomfortable chairs.

Table 3

Linear regression analysis of the effect of difficulty in walking on seat selection in females

(Source: Self-drawing)

\begin{tabular}{|c|c|c|c|c|c|c|c|c|c|}
\hline & \multicolumn{2}{|c|}{ Non-standardized coefficients } & \multirow{2}{*}{$\begin{array}{l}\text { Standardized coefficient } \\
\text { Beta }\end{array}$} & \multirow[t]{2}{*}{$t$} & \multirow[t]{2}{*}{$p$} & \multirow[t]{2}{*}{ VIF } & \multirow[t]{2}{*}{$R^{2}$} & \multirow[t]{2}{*}{ Adjust R2 } & \multirow[t]{2}{*}{$F$} \\
\hline & $B$ & The standard is wrong & & & & & & & \\
\hline constant & 0.041 & 0.027 & - & 1.542 & 0.126 & - & 0.142 & 0.134 & $F(1,113)=18.682, p$ \\
\hline Inconvenience & 0.292 & 0.068 & 0.377 & 4.322 & $0.000 * \star$ & 1.000 & & & \\
\hline
\end{tabular}

Inverse variable: The sofa or chair is too soft to stand up

D-W value: 1.814

* $p<0.05 * * p<0.0$

\begin{tabular}{|c|c|c|c|c|c|c|c|c|c|}
\hline constant & 0.031 & 0.022 & - & 1.392 & 0.167 & - & 0.049 & 0.041 & $F$ \\
\hline Inconvenience & 0.136 & 0.056 & 0.222 & 2.418 & $0.017 *$ & 1.000 & & & $\varepsilon$ \\
\hline
\end{tabular}

Dependent variable: The chair is not easy to move or turn

D-W value: 2.117

* $p<0.05 * * p<0.0$

constant $\quad 0.093$

$0.093 \quad 0.031$

031

2.975

$0.004^{\star *}$

0.008

$-0.001$

Inconvenience $\quad 0.074$

0.079

0.088

0.937

0.351

1.000

Dependents: The chair is not comfortable enough

D-W value: 1.956

${ }^{*} p<0.05$ ** $p<0.01$

constant $\quad 0.031$

0.023

$\begin{array}{ll}- & 1.320\end{array}$

0.190

0.085

0.076

$F(1,11:$

Inconvenience $\quad 0.191 \quad 0.059$

0.291

3.230

$0.002^{\star *}$

1.000

10.432

Dependent variables: There are obstacles to sitting at a table and then standing up

D-W value: 2.121

$* p<0.05 * * p<0.01$

For females, difficulty in walking was the primary factor restricting them from getting up. Females in the age groups of $65-75$ and $75-85$ preferred to sit at home chatting with relatives or friends, so they would use seats more frequently and thus, unsuitable seats would add to their physical inconvenience. Thus, furniture configuration for female aged people should focus on the use of sofas and chairs.

In general, people begin to experience poor eyesight and other eye problems after reaching 50 , and lose brain cells after reaching 60 . This observation is consistent with survey results indicating that aged people in Macao mostly showed declined eyesight and memory. Besides poor eyesight and forgetfulness, male aged people in Macao also complained of weak waist after 65 and difficulty with walking after 75 . These problems probably affected their daily walking and other activities, but did not substantially influence their ability to get up. Male aged people in the age group of 75-85 also reported cervical pain. As for female aged people in Macao, in addition to poor eyesight and forgetfulness, those in the age groups of $\leq 65$ and $75-85$ also experienced cervical pain, and those aged $\geq 85$ showed a series of problems, among which difficulty in walking accounted for a large proportion. 


\subsubsection{Preferences For Living Room Furniture}

The effect of living room area on furniture quantity was explored, and the relationships among living room area, living room furniture quantity, and essential living room furniture were investigated by age groups and gender.

In the model of living room area vs. furniture quantity (see Table 4), living room area exerted a significant positive effect on living room furniture quantity, both in males and females. When gender and age were examined as mediating factors, it was found that neither of them exerted any effect on living room furniture quantity.

Table 4

Summary of the regression coefficients of the model for living room area and living room furniture quantity by gender

(Source: Self-drawing)

\begin{tabular}{|c|c|c|c|c|c|c|c|c|c|}
\hline Gender & $x$ & $\rightarrow$ & $Y$ & Non-standardized path c & efficients & SE & $\begin{array}{l}z(C R \\
\text { value) }\end{array}$ & $p$ & $\begin{array}{l}\text { Standardized } \\
\text { path } \\
\text { coefficients }\end{array}$ \\
\hline \multirow[t]{3}{*}{ Male } & $\begin{array}{l}\text { Living } \\
\text { room area }\end{array}$ & $\rightarrow$ & $\begin{array}{l}\text { Number of living } \\
\text { room furniture }\end{array}$ & 0.023 & & 0.009 & 2.581 & 0.010 & 0.415 \\
\hline & \multicolumn{9}{|c|}{ Note: $\rightarrow$ indicates that the path affects the relationship } \\
\hline & $x$ & $\rightarrow$ & $\mathrm{Y}$ & $\begin{array}{l}\text { Non-standardized path } \\
\text { coefficients }\end{array}$ & SE & & $\begin{array}{l}z(C R \\
\text { value })\end{array}$ & $\mathrm{p}$ & $\begin{array}{l}\text { Standardized path } \\
\text { coefficients }\end{array}$ \\
\hline Female & $\begin{array}{l}\text { Living } \\
\text { room area }\end{array}$ & $\rightarrow$ & $\begin{array}{l}\text { Number of living } \\
\text { room furniture }\end{array}$ & 0.029 & 0.005 & & 5.431 & 0.000 & 0.452 \\
\hline
\end{tabular}

Considering that age did not affect living room furniture quantity as a mediating factor in either males or females, living room area was identified as the primary factor influencing living room furniture quantity. This result directly exhibits the true feelings of aged people about furniture configuration. That is, there should be a proportional relationship between furniture quantity and living room area, as too much or too little furniture would cause discomfort in aged people. Based on the positive effect of living room area on furniture quantity and the proportional relationship between them, the quantity of furniture to be configured for a given living room can be calculated (see Table 5).

Table 5

Analysis of variance between living room area and the number of pieces of living room furniture

\begin{tabular}{|c|c|c|c|c|c|c|}
\hline \multicolumn{7}{|c|}{ (Source: Self-drawing) } \\
\hline & \multicolumn{4}{|c|}{ Number of living room fumiture(Mean \pm standard deviation). } & \multirow[t]{2}{*}{$F$} & \multirow[t]{2}{*}{$p$} \\
\hline & 2-4 pieces(ns 59). & $5-7$ pieces(ns 69). & $8-10(n=18)$ & $11-13$ pieces(ns 1$)$. & & \\
\hline Living room area & $18.19 \pm 8.75$ & $25.84 \pm 10.51$ & $30.78 \pm 11.53$ & $50.00 \pm$ null & 12.406 & $0.000 * *$ \\
\hline \multicolumn{5}{|c|}{$* p<0.05 * * p<0.01$} & & \\
\hline
\end{tabular}

Five types of furniture, i.e., sofas, tea tables, TV racks, dining tables, and dining chairs, are popular among male aged people. Moreover, the furniture demands of people aged $75-85$ and those aged $\geq 85$ were higher than the average level, while the furniture demands (except for essential furniture) of those in the other two groups were lower than the average level. In particular, floor cabinets were deemed unnecessary by people aged $\leq 65$ and people aged $\geq 85$ (see Table 6). Younger aged people had low demands for furniture types, which was likely correlated with their behavioral habits. That is, younger male aged people still had good physical functions, so furniture that could meet basic functional demands would suffice for them. In contrast, furniture for older aged people should also be available for holding and leaning on, and should assist them in their daily activities. 
Table 6

Summary of overlapping between materials selected for living room furniture by males(Source: Self-drawing)

\begin{tabular}{|c|c|c|c|c|c|}
\hline \multirow[t]{2}{*}{ Item } & \multicolumn{4}{|l|}{ Age } & \multirow[t]{2}{*}{ Summary $(n=32)$} \\
\hline & $\begin{array}{l}65 \text { years and below }(n= \\
10)\end{array}$ & $\begin{array}{l}65-75 \text { years old }(n= \\
13)\end{array}$ & $75-85$ years old $(n=5)$ & 85 years old and above $(n=4)$ & \\
\hline couch & $90.00 \%$ & $100.00 \%$ & $100.00 \%$ & $100.00 \%$ & $96.88 \%$ \\
\hline $\begin{array}{l}\text { Sofa side } \\
\text { cabinet }\end{array}$ & $40.00 \%$ & $15.38 \%$ & $60.00 \%$ & $25.00 \%$ & $31.25 \%$ \\
\hline teapoy & $70.00 \%$ & $76.92 \%$ & $100.00 \%$ & $75.00 \%$ & $78.13 \%$ \\
\hline TV cabinet & $70.00 \%$ & $84.62 \%$ & $100.00 \%$ & $100.00 \%$ & $84.38 \%$ \\
\hline table & $40.00 \%$ & $53.85 \%$ & $80.00 \%$ & $50.00 \%$ & $53.13 \%$ \\
\hline Dining chair & $40.00 \%$ & $46.15 \%$ & $80.00 \%$ & $50.00 \%$ & $50.00 \%$ \\
\hline The cabinet & $0.00 \%$ & $7.69 \%$ & $40.00 \%$ & $0.00 \%$ & $9.38 \%$ \\
\hline Shoe cabinet & $10.00 \%$ & $30.77 \%$ & $100.00 \%$ & $25.00 \%$ & $34.38 \%$ \\
\hline Flower & $30.00 \%$ & $23.08 \%$ & $60.00 \%$ & $25.00 \%$ & $31.25 \%$ \\
\hline bookshelf & $10.00 \%$ & $23.08 \%$ & $20.00 \%$ & $25.00 \%$ & $18.75 \%$ \\
\hline Wine cabinet & $10.00 \%$ & $7.69 \%$ & $20.00 \%$ & $25.00 \%$ & $12.50 \%$ \\
\hline The cabinet & $40.00 \%$ & $15.38 \%$ & $40.00 \%$ & $25.00 \%$ & $28.13 \%$ \\
\hline Other & $10.00 \%$ & $0.00 \%$ & $20.00 \%$ & $25.00 \%$ & $9.38 \%$ \\
\hline
\end{tabular}

Sofas, tea tables, TV racks, dining tables, and dining chairs are also popular among female aged people in Macao across different age groups, just as in male aged people. Judging from the age distribution, people aged $\leq 65$ had high demands for storage cabinets. Males in this age group had low demands for furniture other than the above five essential types of furniture, while females in this age group presented the opposite trend. Moreover, females in this age group had high requirements for spatial decorations. Judging from the demands for nonessential furniture, younger female aged people attached greater importance to spatial aesthetics. People aged $\geq 85$ regarded sofa-side cabinets as essential and also preferred bookshelves and wine cabinets compared to average aged people, but they deemed floor cabinets and flower stands as unnecessary and reported less preference for shoeboxes and storage cabinets (see Table 7). Females aged $\geq 85$ paid close attention to the arrangement and display of objects.

Table 7

Summary of overlapping between materials selected for living room furniture by females(Source: Self-drawing)

\begin{tabular}{|c|c|c|c|c|c|}
\hline \multirow[t]{2}{*}{ Item } & \multicolumn{4}{|l|}{ Age } & \multirow{2}{*}{$\begin{array}{l}\text { Summary }(n= \\
115)\end{array}$} \\
\hline & $\begin{array}{l}65 \text { years and below }(n= \\
61)\end{array}$ & $\begin{array}{l}65-75 \text { years old }(n= \\
42)\end{array}$ & $\begin{array}{l}75-85 \text { years old }(n= \\
9)\end{array}$ & $\begin{array}{l}85 \text { years old and above }(n= \\
\text { 3) }\end{array}$ & \\
\hline couch & $96.72 \%$ & $95.24 \%$ & $100.00 \%$ & $100.00 \%$ & $96.52 \%$ \\
\hline $\begin{array}{l}\text { Sofa side } \\
\text { cabinet }\end{array}$ & $44.26 \%$ & $28.57 \%$ & $33.33 \%$ & $100.00 \%$ & $39.13 \%$ \\
\hline teapoy & $81.97 \%$ & $83.33 \%$ & $66.67 \%$ & $100.00 \%$ & $81.74 \%$ \\
\hline TV cabinet & $77.05 \%$ & $83.33 \%$ & $77.78 \%$ & $100.00 \%$ & $80.00 \%$ \\
\hline table & $70.49 \%$ & $66.67 \%$ & $66.67 \%$ & $100.00 \%$ & $69.57 \%$ \\
\hline Dining chair & $62.30 \%$ & $61.90 \%$ & $66.67 \%$ & $100.00 \%$ & $63.48 \%$ \\
\hline The cabinet & $16.39 \%$ & $2.38 \%$ & $0.00 \%$ & $0.00 \%$ & $9.57 \%$ \\
\hline Shoe cabinet & $52.46 \%$ & $50.00 \%$ & $22.22 \%$ & $33.33 \%$ & $48.70 \%$ \\
\hline Flower & $40.98 \%$ & $30.95 \%$ & $22.22 \%$ & $0.00 \%$ & $34.78 \%$ \\
\hline bookshelf & $31.15 \%$ & $19.05 \%$ & $11.11 \%$ & $33.33 \%$ & $25.22 \%$ \\
\hline Wine cabinet & $16.39 \%$ & $19.05 \%$ & $11.11 \%$ & $33.33 \%$ & $17.39 \%$ \\
\hline The cabinet & $52.46 \%$ & $30.95 \%$ & $22.22 \%$ & $33.33 \%$ & $41.74 \%$ \\
\hline Other & $8.20 \%$ & $16.67 \%$ & $11.11 \%$ & $0.00 \%$ & $11.30 \%$ \\
\hline
\end{tabular}


Data analysis showed that the quantity of living room furniture was only affected by the living room area, and was independent of gender or age. The three most essential types of living room furniture were sofas, tea tables, and TV racks. Males aged 75-85 also expressed high demands for other types of furniture, and for them, a living room is a combination of the existing entrance hall, living room, and dining hall. Female aged people in Macao also tended to include the dining hall as a part of the living room. Those aged $\leq 65$ obviously had comprehensive demands for furniture types, and, for them, a living room should also include storage spaces and decorations, as well as the entrance hall, living room, and dining hall. This means that furniture configuration for younger female aged people should include spatial decorations. People aged $65-75$ and those aged $\geq 85$ stressed the storage and display of objects, both out of habits and for the sake of tidiness.

\subsubsection{Material Selection For Living Room Furniture}

The analysis of the preferences of aged people for living room furniture showed that five types of furniture, i.e., sofas, tea tables, TV racks, dining tables, and dining chairs, were most popular. The following presents an analysis on the materials selected by aged people for these five types of furniture.

(1) Materials for sofas

Overall (see Table 8), males preferred fabrics, leather, and solid wood as materials for sofas. Males aged $\leq 65$ expressed basically equal preferences for these three materials, and could also accept bamboo-plaited and rattan-plaited sofas. Those aged 65-75 showed low preferences for leather, but expressed aboveaverage preferences for solid wood and could also accept rattan-plaited sofas. Those aged 75-85 manifested consistent preferences for materials, and only selected fabrics and leather. Starting with this age group, the number of males who experienced difficulty with walking and weak waist increased substantially; therefore,visually soft and comfortable fabrics and leather appealed to them. Those aged $\geq 85$ expressed above-average preferences for solid wood, but less preferences for fabrics. This was because stable wooden furniture could serve as supporting points for aged people and assist them in getting up or taking a rest.

Table 8

Summary of overlapping between materials selected for sofas by males and females(Source: Self-drawing)

\begin{tabular}{|c|c|c|c|c|c|c|}
\hline \multirow[t]{2}{*}{ Gender } & \multirow[t]{2}{*}{ Item } & \multicolumn{4}{|l|}{ Age } & \multirow[t]{2}{*}{ Summary $(n=32)$} \\
\hline & & $\begin{array}{l}65 \text { years and below }(n= \\
10)\end{array}$ & $\begin{array}{l}65-75 \text { years old }(n= \\
\text { 13) }\end{array}$ & $\begin{array}{l}75-85 \text { years old }(n= \\
5)\end{array}$ & $\begin{array}{l}85 \text { years old and above }(n= \\
\text { 4) }\end{array}$ & \\
\hline \multirow[t]{11}{*}{ Male } & Fabric & $40.00 \%$ & $46.15 \%$ & $100.00 \%$ & $25.00 \%$ & $50.00 \%$ \\
\hline & Rattan & $10.00 \%$ & $15.38 \%$ & $0.00 \%$ & $0.00 \%$ & $9.38 \%$ \\
\hline & leather & $30.00 \%$ & $15.38 \%$ & $40.00 \%$ & $25.00 \%$ & $25.00 \%$ \\
\hline & $\begin{array}{l}\text { Solid } \\
\text { wood }\end{array}$ & $30.00 \%$ & $53.85 \%$ & $0.00 \%$ & $75.00 \%$ & $40.63 \%$ \\
\hline & Panel & $0.00 \%$ & $0.00 \%$ & $0.00 \%$ & $0.00 \%$ & $0.00 \%$ \\
\hline & metal & $0.00 \%$ & $0.00 \%$ & $0.00 \%$ & $0.00 \%$ & $0.00 \%$ \\
\hline & Bamboo & $10.00 \%$ & $0.00 \%$ & $0.00 \%$ & $0.00 \%$ & $3.13 \%$ \\
\hline & Other & $0.00 \%$ & $0.00 \%$ & $0.00 \%$ & $0.00 \%$ & $0.00 \%$ \\
\hline & \multicolumn{6}{|c|}{ The card side " 2is 11.415 p. .. 0.494} \\
\hline & \multirow[t]{2}{*}{ Item } & \multicolumn{4}{|l|}{ Age } & \multirow{2}{*}{$\begin{array}{l}\text { Summary }(n= \\
115)\end{array}$} \\
\hline & & $\begin{array}{l}65 \text { years and below }(n= \\
61)\end{array}$ & $\begin{array}{l}65-75 \text { years old }(n= \\
42)\end{array}$ & $\begin{array}{l}75-85 \text { years old }(n= \\
9)\end{array}$ & $\begin{array}{l}85 \text { years old and above }(n= \\
\text { 3) }\end{array}$ & \\
\hline \multirow[t]{8}{*}{ Female } & Fabric & $73.77 \%$ & $61.90 \%$ & $55.56 \%$ & $33.33 \%$ & $66.96 \%$ \\
\hline & Rattan & $9.84 \%$ & $2.38 \%$ & $0.00 \%$ & $0.00 \%$ & $6.09 \%$ \\
\hline & leather & $18.03 \%$ & $26.19 \%$ & $0.00 \%$ & $33.33 \%$ & $20.00 \%$ \\
\hline & $\begin{array}{l}\text { Solid } \\
\text { wood }\end{array}$ & $44.26 \%$ & $38.10 \%$ & $77.78 \%$ & $33.33 \%$ & $44.35 \%$ \\
\hline & Panel & $0.00 \%$ & $0.00 \%$ & $0.00 \%$ & $0.00 \%$ & $0.00 \%$ \\
\hline & metal & $0.00 \%$ & $0.00 \%$ & $0.00 \%$ & $0.00 \%$ & $0.00 \%$ \\
\hline & Bamboo & $3.28 \%$ & $0.00 \%$ & $0.00 \%$ & $0.00 \%$ & $1.74 \%$ \\
\hline & Other & $1.64 \%$ & $4.76 \%$ & $0.00 \%$ & $0.00 \%$ & $2.61 \%$ \\
\hline
\end{tabular}

In contrast, fabrics and solid wood were most popular among female aged people as materials for sofas. Judging from age distribution, females aged $\leq 65$, just like males in the same age group, could accept rattan-plaited and bamboo-plaited sofas. Those aged 65-75 could also accept rattan-plaited sofas, and 
expressed above-average preferences for leather. Clearly, younger aged people had more options in mind as furniture materials, had a high acceptance threshold, and were willing to try multiple styles. Females aged 75-85 presented consistent preferences for materials, which were limited to fabrics and solid wood. Those aged $\geq 85$ expressed basically equal preferences for fabrics, leather, and solid wood. On the whole, females showed moderate acceptance of leather, but their average acceptance decreased by those aged 75-85 who disliked leather. Compared to males, females had more scattered material options, and expressed more preferences for soft materials. However, it should be noted that, with growing age, females also begin to face problems of weak waist and difficulty with walking, so their furniture materials should not be excessively soft.

(2) Materials for tea tables

According to the overall data statistics, male and female aged people manifested consistent preferences for tea table materials across different age groups. Males in all age groups selected wood, and a very high proportion of females also selected wood. Glass was either used to match the wood, orwas used alone.

(3) Materials for dining tables and chairs

Dining tables and chairs are usually purchased in sets, which is why they are discussed together in this paper. The "Others" column related to materials for dining tables was filled with "Glass" by all respondents, which is why "Others" was directly changed to "Glass".

The preferences of male aged people in Macao for wooden furniture continued in the selection of dining table materials. All respondents consistently selected wooden dining tables. Metals constituted a special choice for people aged $65-75$. Rattan-plaited dining tables were accepted by the age groups of $\leq 65$ and $65-75$, just as in the case of the selection of sofa materials. The young aged people pay close attention to the matching and unity of furniture materials. Glass and metals were probably selected to match the wood (see Table 9). Wood was also the primary choice of dining chair materials. The only age group that selected fabrics was the age group of $\leq 65$. People aged $75-85$ also embraced metal and rattan-plaited dining chairs. Leather was only selected by people aged 65-75.

Table 9

Summary of overlapping between materials selected for dining tables and chairs by males(Source: Self-drawing)

\begin{tabular}{|c|c|c|c|c|c|c|}
\hline \multirow[t]{2}{*}{ Furniture } & \multirow[t]{2}{*}{ Item } & \multicolumn{4}{|l|}{ Age } & \multirow{2}{*}{$\begin{array}{l}\text { Summary }(n= \\
\text { 32) }\end{array}$} \\
\hline & & $\begin{array}{l}65 \text { years and below }(n= \\
10)\end{array}$ & $\begin{array}{l}65-75 \text { years old }(n= \\
13)\end{array}$ & $\begin{array}{l}75-85 \text { years old }(n= \\
5)\end{array}$ & $\begin{array}{l}85 \text { years old and above }(n= \\
4)\end{array}$ & \\
\hline \multirow[t]{9}{*}{ Table } & wooden & $100.00 \%$ & $100.00 \%$ & $100.00 \%$ & $100.00 \%$ & $100.00 \%$ \\
\hline & Panel & $0.00 \%$ & $0.00 \%$ & $0.00 \%$ & $0.00 \%$ & $0.00 \%$ \\
\hline & metal & $0.00 \%$ & $7.69 \%$ & $0.00 \%$ & $0.00 \%$ & $3.13 \%$ \\
\hline & plastics & $0.00 \%$ & $0.00 \%$ & $0.00 \%$ & $0.00 \%$ & $0.00 \%$ \\
\hline & Rattan & $10.00 \%$ & $7.69 \%$ & $0.00 \%$ & $0.00 \%$ & $6.25 \%$ \\
\hline & glass & $10.00 \%$ & $0.00 \%$ & $20.00 \%$ & $0.00 \%$ & $6.25 \%$ \\
\hline & \multicolumn{6}{|c|}{ Card's 2018: f-4.972 p-0.837 } \\
\hline & \multirow[t]{2}{*}{ Item } & \multicolumn{4}{|l|}{ Age } & \multirow{2}{*}{$\begin{array}{l}\text { Summary (ns } \\
32) \text {. }\end{array}$} \\
\hline & & $\begin{array}{l}65 \text { years and below }(n= \\
10)\end{array}$ & $\begin{array}{l}65-75 \text { years old }(n= \\
\text { 13) }\end{array}$ & $\begin{array}{l}75-85 \text { years old }(n= \\
5)\end{array}$ & $\begin{array}{l}85 \text { years old and above }(n= \\
\text { 4) }\end{array}$ & \\
\hline \multirow{8}{*}{$\begin{array}{l}\text { Dining } \\
\text { chair }\end{array}$} & wooden & $100.00 \%$ & $92.31 \%$ & $100.00 \%$ & $100.00 \%$ & $96.88 \%$ \\
\hline & Panel & $0.00 \%$ & $0.00 \%$ & $0.00 \%$ & $0.00 \%$ & $0.00 \%$ \\
\hline & Fabric & $30.00 \%$ & $0.00 \%$ & $0.00 \%$ & $0.00 \%$ & $9.38 \%$ \\
\hline & metal & $0.00 \%$ & $7.69 \%$ & $20.00 \%$ & $0.00 \%$ & $6.25 \%$ \\
\hline & plastics & $0.00 \%$ & $0.00 \%$ & $0.00 \%$ & $0.00 \%$ & $0.00 \%$ \\
\hline & Rattan & $10.00 \%$ & $15.38 \%$ & $20.00 \%$ & $0.00 \%$ & $12.50 \%$ \\
\hline & leather & $0.00 \%$ & $7.69 \%$ & $0.00 \%$ & $0.00 \%$ & $3.13 \%$ \\
\hline & Other & $0.00 \%$ & $0.00 \%$ & $20.00 \%$ & $0.00 \%$ & $3.13 \%$ \\
\hline
\end{tabular}

According to Table 10, there was a high positive correlation between rattan-plaited dining tables and chairs in males, as males choosing rattan-plaited dining chairs were unlikely to use wooden dining chairs. There was also a high positive correlation between leather dining chairs and metal dining tables. Fabric dining chairs were often matched with glass dining tables. Generally, different material combinations can change the style of interior spaces. When only few different materials are available, attention should be paid to the matching and unity of materials favored by aged people. 
Table 10

Summary of correlation between materials selected for dining tables and chairs by males(Source: Self-drawing)

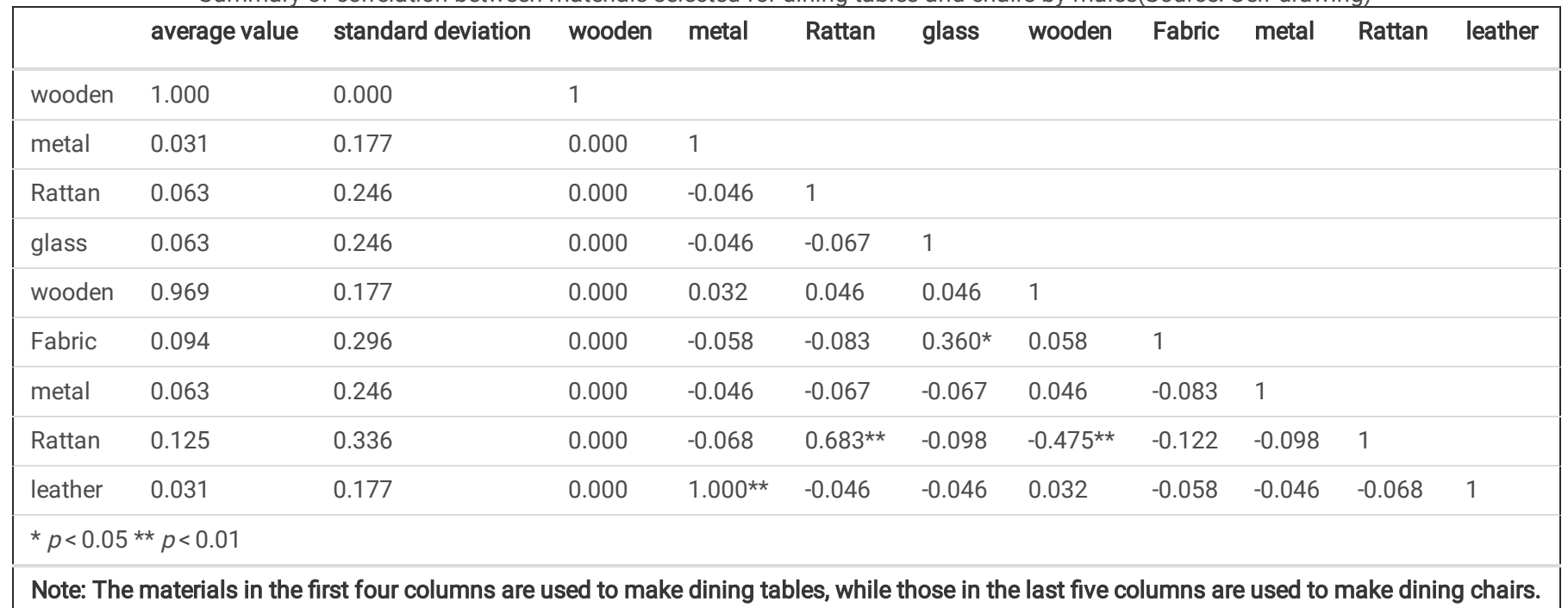

With regard to dining tables, females had a diversified range of materials in mind, among which wood was still the primary choice. Some females in the age groups of $\leq 65$ and 65-75 selected artificial board, which has light weight and a similar appearance to solid wood, making it convenient for flexible use and movement of furniture. An obviously higher proportion of females in the age group of 75-85 selected rattan-plaited furniture than those in the other age groups. Wood also played a dominant role in the possible materials for dining chairs. More women selected fabrics as the material for dining chairs, similar to the case of the selection of sofa materials, suggesting that females prefer materials that visually appear soft and comfortable. Various age groups expressed basically equal preferences for rattan-plaited dining chair and rattan-plaited dining tables. Leather was selected by people in the age groups of $\leq 65$ and $65-$ 75 (see Table 11).

Table 11

Summary of overlapping between materials selected for dining tables and chairs by females(Source: Self-drawing)

\begin{tabular}{|c|c|c|c|c|c|c|}
\hline \multirow[t]{2}{*}{ Furniture } & \multirow[t]{2}{*}{ Item } & \multicolumn{4}{|l|}{ Age } & \multirow{2}{*}{$\begin{array}{l}\text { Summary }(n= \\
115)\end{array}$} \\
\hline & & $\begin{array}{l}65 \text { years and below }(n= \\
61)\end{array}$ & $\begin{array}{l}65-75 \text { years old }(n= \\
42)\end{array}$ & $\begin{array}{l}75-85 \text { years old }(n= \\
9)\end{array}$ & $\begin{array}{l}85 \text { years old and above }(n= \\
\text { 3) }\end{array}$ & \\
\hline \multirow[t]{9}{*}{ Table } & wooden & $98.36 \%$ & $95.24 \%$ & $100.00 \%$ & $100.00 \%$ & $97.39 \%$ \\
\hline & Panel & $6.56 \%$ & $2.38 \%$ & $0.00 \%$ & $0.00 \%$ & $4.35 \%$ \\
\hline & metal & $4.92 \%$ & $0.00 \%$ & $0.00 \%$ & $0.00 \%$ & $2.61 \%$ \\
\hline & plastics & $0.00 \%$ & $0.00 \%$ & $0.00 \%$ & $0.00 \%$ & $0.00 \%$ \\
\hline & Rattan & $8.20 \%$ & $4.76 \%$ & $22.22 \%$ & $0.00 \%$ & $7.83 \%$ \\
\hline & glass & $4.92 \%$ & $7.14 \%$ & $0.00 \%$ & $0.00 \%$ & $5.22 \%$ \\
\hline & \multicolumn{6}{|c|}{ The 2018 year of the card side: $\mathrm{f}$ is $7.883 p .794$} \\
\hline & \multirow[t]{2}{*}{ Item } & \multicolumn{4}{|l|}{ Age } & \multirow{2}{*}{$\begin{array}{l}\text { Summary (ns } \\
115) .\end{array}$} \\
\hline & & $\begin{array}{l}65 \text { years and below }(n= \\
61)\end{array}$ & $\begin{array}{l}65-75 \text { years old }(n= \\
42)\end{array}$ & $\begin{array}{l}75-85 \text { years old }(n= \\
9)\end{array}$ & $\begin{array}{l}85 \text { years old and above }(n= \\
\text { 3) }\end{array}$ & \\
\hline \multirow{9}{*}{$\begin{array}{l}\text { Dining } \\
\text { chair }\end{array}$} & wooden & $91.80 \%$ & $92.86 \%$ & $100.00 \%$ & $100.00 \%$ & $93.04 \%$ \\
\hline & Panel & $3.28 \%$ & $0.00 \%$ & $0.00 \%$ & $0.00 \%$ & $1.74 \%$ \\
\hline & Fabric & $21.31 \%$ & $11.90 \%$ & $22.22 \%$ & $0.00 \%$ & $17.39 \%$ \\
\hline & metal & $1.64 \%$ & $2.38 \%$ & $0.00 \%$ & $0.00 \%$ & $1.74 \%$ \\
\hline & plastics & $1.64 \%$ & $0.00 \%$ & $0.00 \%$ & $0.00 \%$ & $0.87 \%$ \\
\hline & Rattan & $13.11 \%$ & $4.76 \%$ & $22.22 \%$ & $0.00 \%$ & $10.43 \%$ \\
\hline & leather & $3.28 \%$ & $2.38 \%$ & $0.00 \%$ & $0.00 \%$ & $2.61 \%$ \\
\hline & Other & $0.00 \%$ & $4.76 \%$ & $0.00 \%$ & $0.00 \%$ & $1.74 \%$ \\
\hline & \multicolumn{6}{|c|}{ The 2018 of the card side: $\mathrm{f}$ is $11.523 p .952$} \\
\hline
\end{tabular}

Wooden dining tables were significantly positively correlated with wooden dining chairs, but clearly negatively correlated with artificial board and metal dining chairs. Judging from the selection of artificial board and wood, there was an obvious division, as wooden furniture presents more lasting appeal (although 
less flexibility) than artificial board furniture. So far, artificial board furniture still cannot replace wooden furniture. There was a positive correlation between artificial board dining tables and chairs, as well as between rattan-plaited dining tables and chairs. Glass dining tables were negatively correlated with wooden dining chairs, but positively correlated with metal chairs (see Table 12).

Table 12

Summary of correlation between materials selected for dining tables and chairs by female(Source: Self-drawing)

\begin{tabular}{|c|c|c|c|c|c|c|c|c|c|c|c|c|c|}
\hline & $\begin{array}{l}\text { average } \\
\text { value }\end{array}$ & $\begin{array}{l}\text { standard } \\
\text { deviation }\end{array}$ & 1 & 2 & 3 & 4 & 5 & 6 & 7 & 8 & 9 & 10 & 11 \\
\hline Wood (1) & 0.974 & 0.160 & 1 & & & & & & & & & & \\
\hline $\begin{array}{l}\text { Artificial } \\
\text { plate (2) }\end{array}$ & 0.043 & 0.205 & $-0.500 * \star$ & 1 & & & & & & & & & \\
\hline Metals (3) & 0.026 & 0.160 & $-0.315^{\star \star}$ & $0.233^{*}$ & 1 & & & & & & & & \\
\hline Vine (4) & 0.078 & 0.270 & 0.048 & -0.062 & -0.048 & 1 & & & & & & & \\
\hline Glass (5) & 0.052 & 0.223 & $-0.207^{*}$ & -0.050 & -0.038 & -0.068 & 1 & & & & & & \\
\hline Wood (6) & 0.930 & 0.256 & $0.384^{\star \star}$ & -0.109 & -0.170 & -0.048 & $-0.243^{\star \star}$ & 1 & & & & & \\
\hline $\begin{array}{l}\text { Artificial } \\
\text { plate (7) }\end{array}$ & 0.017 & 0.131 & $-0.396^{\star \star}$ & $0.624^{\star *}$ & $0.396^{\star *}$ & -0.039 & -0.031 & $-0.225^{*}$ & 1 & & & & \\
\hline Fabric (8) & 0.174 & 0.381 & 0.075 & 0.127 & 0.069 & 0.037 & 0.099 & $-0.416^{\star \star}$ & -0.061 & 1 & & & \\
\hline Vine (9) & 0.104 & 0.307 & 0.056 & -0.073 & -0.056 & $0.642^{\star \star}$ & 0.176 & -0.130 & -0.045 & -0.007 & 1 & & \\
\hline $\begin{array}{l}\text { Leather } \\
\text { (10) }\end{array}$ & 0.026 & 0.160 & 0.027 & -0.035 & $0.315^{\star \star}$ & -0.048 & -0.038 & 0.045 & -0.022 & -0.075 & -0.056 & 1 & \\
\hline $\begin{array}{l}\text { Metals } \\
\text { (11) }\end{array}$ & 0.017 & 0.131 & $-0.813^{\star \star}$ & $0.298^{* \star}$ & $0.396^{\star *}$ & -0.039 & $0.268^{\star *}$ & $-0.487^{\star \star}$ & $0.491^{\star \star}$ & -0.061 & -0.045 & -0.022 & 1 \\
\hline \multicolumn{14}{|c|}{${ }^{*} p<0.05 * * p<0.01$} \\
\hline
\end{tabular}

\section{(4) TV rack materials}

With regard to the selection of TV rack materials, male and female aged people manifested a consistent preference for wood across different age groups. Other materials were probably selected to match the wood. To be specific, metals were selected by males in the age groups of 75-85 and $\geq 85$. Glass was selected by males in the age groups of $\leq 65$ and $65-75$. Females differed significantly from males in the age group of $75-85$, in which wood and metals were selected at different times.

(5) Weights of furniture features

Differences were observed between male and female respondents in aesthetics, unity with interior style, and furniture use frequency (see Table 13). Gender showed significant differences in aesthetics, and the average value of males (3.81) was obviously lower than that of females (4.57). With regard to unity of interior style, the average value of males (3.84) was also obviously lower than that of females (4.42). These two results suggest that females attach greater importance to the aesthetics and unity with their interior style of furniture. Females also showed a higher acceptance of furniture materials than males. In terms of furniture use frequency, the average value of males (4.66) was obviously higher than that of females (3.97), suggesting that males likely emphasize furniture use frequency more than females.

Table 13

ANOVA of weights of furniture features by gender(Source: Self-drawing)

\begin{tabular}{|c|c|c|c|c|}
\hline & \multicolumn{2}{|c|}{ Gender (Mean \pm standard). } & \multirow[t]{2}{*}{$F$} & \multirow[t]{2}{*}{$p$} \\
\hline & $\operatorname{Male}(n=32)$ & Female $(n=115)$ & & \\
\hline Easy to use & $4.84 \pm 0.37$ & $4.59 \pm 0.92$ & 2.313 & 0.130 \\
\hline The layout is reasonable & $4.63 \pm 0.83$ & $4.52 \pm 1.00$ & 0.284 & 0.595 \\
\hline Aesthetics & $3.81 \pm 1.00$ & $4.57 \pm 0.70$ & 24.190 & $0.000 * *$ \\
\hline Comfort & $4.81 \pm 0.40$ & $4.52 \pm 0.99$ & 2.610 & 0.108 \\
\hline It's in harmony with the interior style & $3.84 \pm 0.99$ & $4.42 \pm 0.88$ & 10.107 & $0.002^{\star *}$ \\
\hline Flexible use & $4.19 \pm 0.82$ & $3.91 \pm 1.01$ & 1.981 & 0.161 \\
\hline Frequency of use & $4.66 \pm 0.48$ & $3.97 \pm 1.08$ & 12.060 & $0.001 * *$ \\
\hline$* p<0.05 * * p<0.01$ & & & & \\
\hline
\end{tabular}


Age produced obvious differences in unity with interior style (see Table 14). The average value of the age group of $\leq 65$ was obviously higher than the average values of the other three age groups. In turn, the average value of the age group of 65-75 was higher than the average values of the other two groups. Clearly, age exerted a negative effect on the weight of unity with interior style. Young aged people still had the energy to match interior furniture, and improve their living conditions.

Table 14

ANOVA of weights of furniture features by gender and age(Source: Self-drawing)

\begin{tabular}{|c|c|c|c|c|c|c|c|}
\hline \multirow[t]{2}{*}{ Gender } & & \multicolumn{4}{|c|}{ Age(Mean \pm standard deviation) } & \multirow[t]{2}{*}{$F$} & \multirow[t]{2}{*}{$p$} \\
\hline & & $\begin{array}{l}65 \text { years and } \\
\text { below }(n=10)\end{array}$ & $\begin{array}{l}65-75 \text { years old }(n \\
=13)\end{array}$ & $\begin{array}{l}75-85 \text { years } \\
\text { old }(n=5)\end{array}$ & $\begin{array}{l}85 \text { years old and } \\
\text { above }(n=4)\end{array}$ & & \\
\hline \multirow[t]{10}{*}{ Male } & Easy to use & $5.00 \pm 0.00$ & $4.77 \pm 0.44$ & $4.80 \pm 0.45$ & $4.75 \pm 0.50$ & 0.874 & 0.467 \\
\hline & The layout is reasonable & $5.00 \pm 0.00$ & $4.54 \pm 0.66$ & $4.20 \pm 1.79$ & $4.50 \pm 0.58$ & 1.211 & 0.324 \\
\hline & Aesthetics & $4.40 \pm 0.70$ & $3.77 \pm 0.93$ & $3.00 \pm 1.41$ & $3.50 \pm 0.58$ & 2.822 & 0.057 \\
\hline & Comfort & $4.90 \pm 0.32$ & $4.77 \pm 0.44$ & $5.00 \pm 0.00$ & $4.50 \pm 0.58$ & 1.480 & 0.241 \\
\hline & $\begin{array}{l}\text { It's in harmony with the } \\
\text { interior style }\end{array}$ & $4.60 \pm 0.52$ & $3.92 \pm 0.86$ & $2.80 \pm 0.84$ & $3.00 \pm 0.82$ & 8.160 & $0.000 * *$ \\
\hline & Flexible use & $4.40 \pm 0.84$ & $4.15 \pm 0.69$ & $4.00 \pm 1.22$ & $4.00 \pm 0.82$ & 0.364 & 0.780 \\
\hline & Frequency of use & $4.80 \pm 0.42$ & $4.54 \pm 0.52$ & $4.60 \pm 0.55$ & $4.75 \pm 0.50$ & 0.603 & 0.619 \\
\hline & \multicolumn{7}{|l|}{$* p<0.05 * * p<0.01$} \\
\hline & & \multicolumn{4}{|c|}{ Age(Mean \pm standard deviation) } & $F$ & $p$ \\
\hline & & $\begin{array}{l}65 \text { years and } \\
\text { below }(n=61)\end{array}$ & $\begin{array}{l}65-75 \text { years old }(n \\
=42)\end{array}$ & $\begin{array}{l}75-85 \text { years } \\
\text { old }(n=9)\end{array}$ & $\begin{array}{l}85 \text { years old and } \\
\text { above }(n=3)\end{array}$ & & \\
\hline \multirow[t]{8}{*}{ Female } & Easy to use & $4.51 \pm 1.15$ & $4.67 \pm 0.57$ & $4.67 \pm 0.50$ & $5.00 \pm 0.00$ & 0.474 & 0.701 \\
\hline & The layout is reasonable & $4.44 \pm 1.20$ & $4.64 \pm 0.69$ & $4.44 \pm 0.88$ & $4.67 \pm 0.58$ & 0.363 & 0.780 \\
\hline & Aesthetics & $4.75 \pm 0.47$ & $4.43 \pm 0.89$ & $4.11 \pm 0.78$ & $4.33 \pm 0.58$ & 3.594 & $0.016^{*}$ \\
\hline & Comfort & $4.44 \pm 1.18$ & $4.57 \pm 0.80$ & $4.67 \pm 0.50$ & $5.00 \pm 0.00$ & 0.452 & 0.716 \\
\hline & $\begin{array}{l}\text { It's in harmony with the } \\
\text { interior style }\end{array}$ & $4.49 \pm 1.01$ & $4.57 \pm 0.55$ & $3.56 \pm 0.53$ & $3.33 \pm 0.58$ & 5.590 & $0.001^{\star \star}$ \\
\hline & Flexible use & $3.82 \pm 0.94$ & $4.02 \pm 1.12$ & $4.22 \pm 1.09$ & $3.33 \pm 0.58$ & 0.945 & 0.422 \\
\hline & Frequency of use & $3.87 \pm 1.06$ & $3.95 \pm 1.17$ & $4.44 \pm 0.73$ & $5.00 \pm 0.00$ & 1.702 & 0.171 \\
\hline & ${ }^{*} p<0.05 * \star p<0.01$ & & & & & & \\
\hline
\end{tabular}

With regard to female aged people in Macao, age produced significant differences in aesthetics and unity with interior style. To be specific, the weights assigned to aesthetics by people aged $\leq 65$ were higher than those assigned to aesthetics by people aged $65-85$. Judging from these two aspects, younger female aged people tended to have higher requirements for the aesthetics and unity with the interior furniture style. This is similar to the case of males, and thus, similar conclusions can be drawn.

In Macao, younger aged people had a higher acceptance and wider options of furniture materials. Wood was the primary material both males and females favored. To be specific, males and females in the age group of 75-85 only accepted fabric or leather sofas. Compared to males, females preferred fabric sofas, followed by solid wood sofas. People in all age groups selected solid wood and glass as the materials for tea tables. Dining tables and chairs are usually purchased in sets and therefore, in this study, dining tables and chairs made of the same material were positively correlated. All male aged people selected wooden dining tables and chairs, while females had a wider range of materials for dining tables and chairs and showed higher preferences for artificial board, rattan-plaited, and fabric dining tables and chairs then males. All male aged people selected wooden TV racks, but the options of metals, artificial boar, and glass were distributed throughout different age groups. A very high proportion of females selected wooden TV racks, but their acceptance of other materials and types was uniformly higher than that of males.

All aged people in Macao placed strong emphasis on the convenience and comfort of furniture. Compared to females, males reported lower requirements for aesthetics and unity with interior style, but higher requirements for furniture use frequency. In terms of age distribution, the importance attached by both males and females to aesthetics and unity with interior style declined with increasing age, but the importance attached to flexible use increased with increasing age and increasing physical inconvenience.

\section{Discussion And Conclusions}

With the emphasis of the ageing problem across the society and the increase of quality elderly care communities, more and more aged people will accept home care. This paper explores the differences among different types of aged people with regard to physical functions, activities, and furniture demands, 
summarizes the preferences of different types of aged people, and identifies the problems in need of attention. The findings of this paper provide preliminary criteria on living room furniture configuration for aged people, and lay a basis for improving their quality of life and happiness index.

Taking the Youhan Community of Macau as a case study, the physical changes, living conditions, furniture configuration, and material preferences of aged people were analyzed. The findings showed that the furniture preferences of aged people varied across different gender and age groups. Compared to females, males preferred outdoor activities, mostly suffered from problems of weak waist and difficulty with walking, manifested relatively consistent tendencies in the selection of furniture materials, and attached greater importance to the flexible use and use frequency of their furniture. In contrast, females spent more time at home, so they had higher requirements for seats, showed a high acceptance of diversified furniture materials, and paid closer attention to the aesthetics and unity with interior style of furniture. Relative to older aged people, younger aged people accepted a wider range of furniture material options. The importance attached to the aesthetics and unity with interior style of furniture declined with increasing age, but the importance attached to flexible use increased with increasing age. The differences across gender and age groups cannot be treated by making sweeping generalizations. To that end, a preliminarily table of furniture configuration was created for different types of aged people in Macau based on their specific demands.

This paper only focuses on the demands of aged people for living room furniture. The findings showed that aged people of different gender and age groups have very different demands. Currently, research on elderly furniture and elderly residences is being advanced continuously, and interior furniture configuration for elderly people receives particularly close attention. It is the author's sincere hope that, by more thoroughly and comprehensively investigating the demands of different types of aged people, more life conveniences can be created for aged people and a referential furniture configuration table can be provided for building quality elderly care communities. Consequently, elderly people can enjoy their remaining years in comfort.

\section{References}

[1] Leung's Consultants Co., Ltd. 2004. Macau Special Administrative Region-Research Report on the Elderly Care Supply System. Publication: Macau Special Administrative Region Social Work Bureau.

[2] Mei Jianping. Research on the furniture configuration and comfort of urban residential space[D]. Nanjing Forestry University, 2006.

[3]Qu Huize. Furniture design for the elderly[J]. Forestry Machinery and Woodworking Equipment, 2016, 44(12): 26-28.

[4] Wang Dehai. Research on home care for the aged and its housing adaptability design[D]. Tongji University, 2007.

[5]Tao Mingyang. Research on the design of modular mobile communication products for the elderly [D]. Hunan University, 2011.

[6]Crews, Douglas E, and Susan Zavotka. “Aging, Disability, and Frailty: Implications for Universal Design.” Journal of physiological anthropology 25.1 (2006): 113-118. Web.

[7] Liu Fangxin. Research on the Universal Design of Modern Urban Residential Space [D]. Nanchang University, 2012.

[8] Huang Huashi. Research on the design of existing residential areas to adapt to the renewal and renovation of buildings for the elderly [D]. Hunan University, 2012.

[9]Xu Leiqing. Research on the spatial cognition and satisfaction of squares[J]. Journal of Tongji University (Natural Science Edition), 2006(02):181-185.

[10]Liu Min. Research on furniture configuration of residential interior space [D]. Beijing Forestry University, 2006.

[11] Chai Xinying. Research on Residential Space Furniture Configuration[J]. Beauty and Times (Urban Edition), 2015(07): 58-59.

[12]Chen Yinhui. Research on the life behavior and furniture design of the elderly [D]. Nanjing Forestry University, 2008.

\section{Figures}

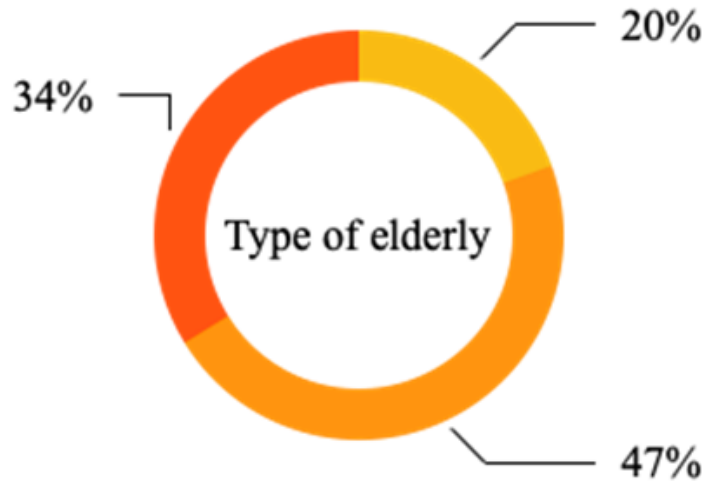

SelF-helping Aged People
Device-helping Aged People
Under Nursing Aged People

Page $16 / 18$ 
Figure 1

Type of elderly (Source: Self-drawing)
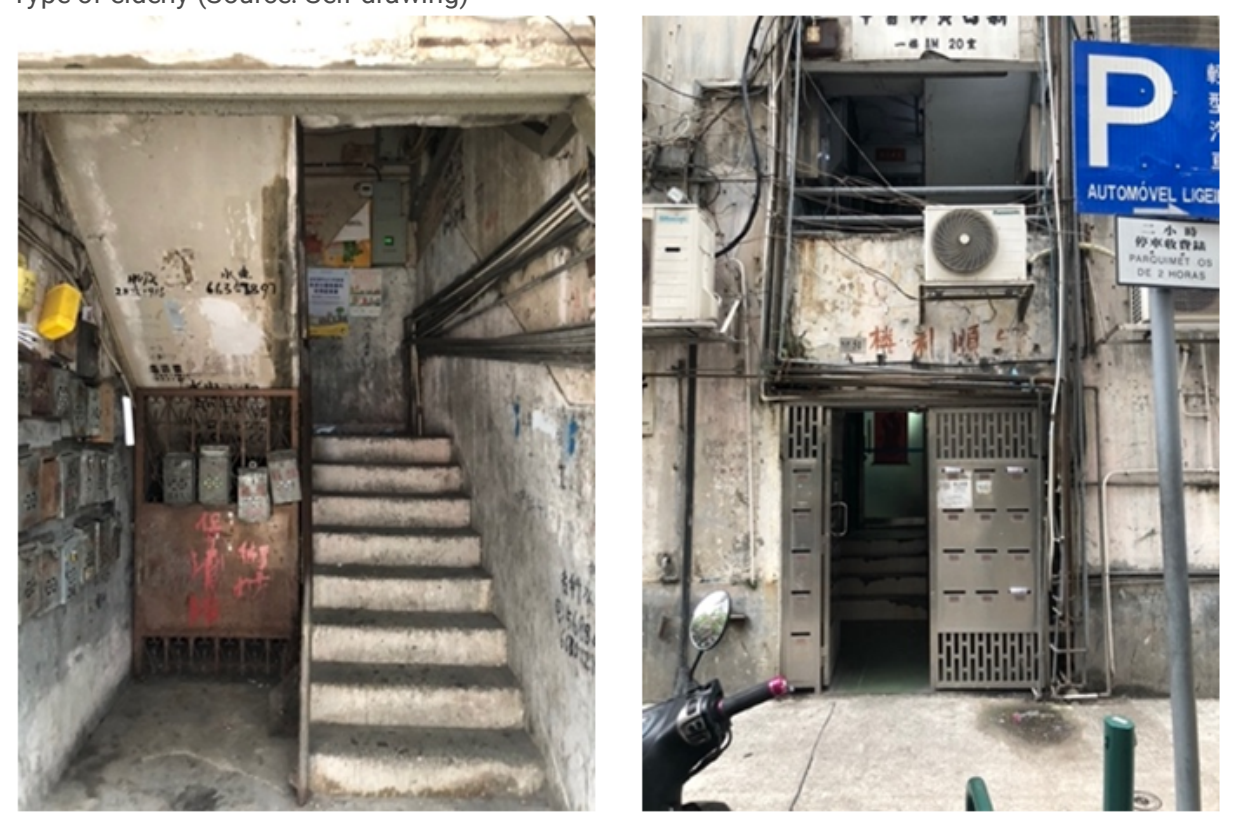

Figure 2

Status of Youhan Community (Source: Self-drawing)
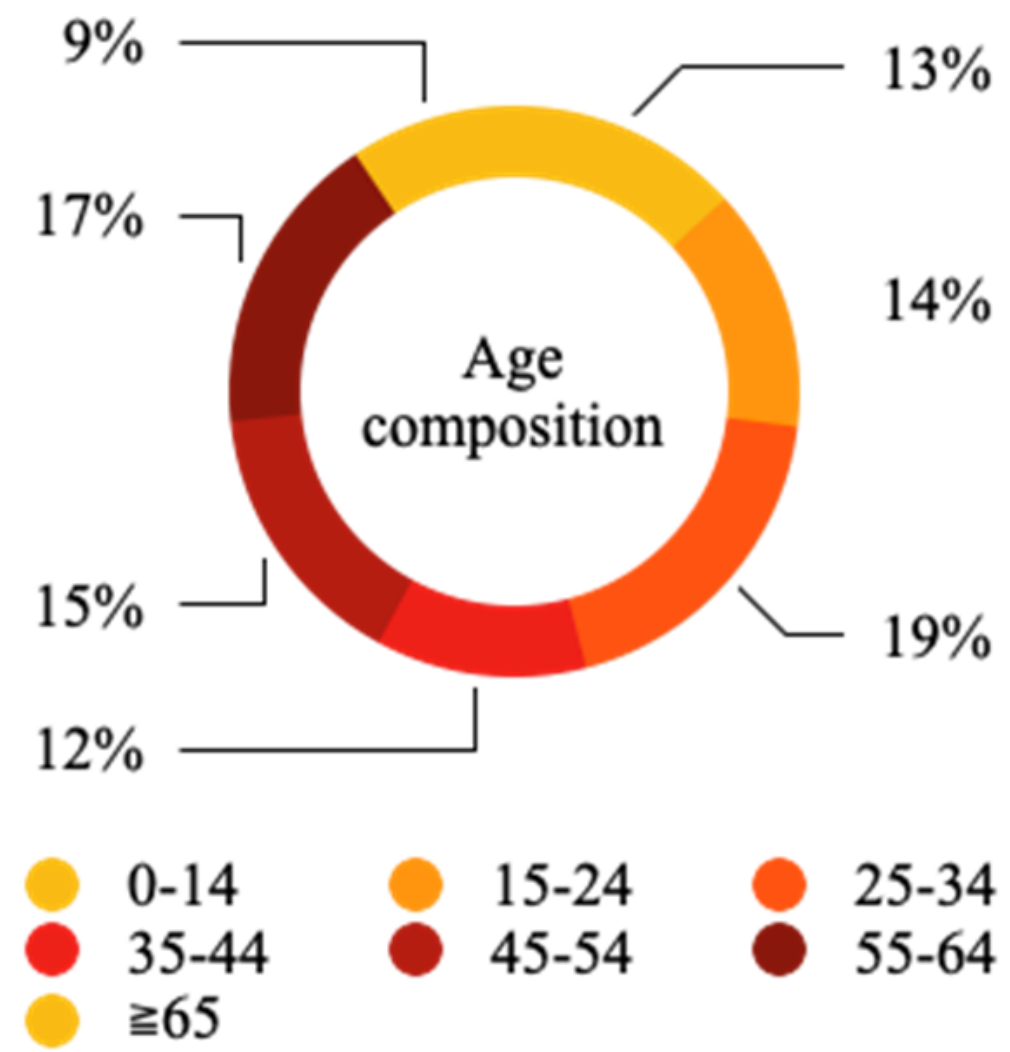

Figure 3

Age composition (Source: Self-drawing) 

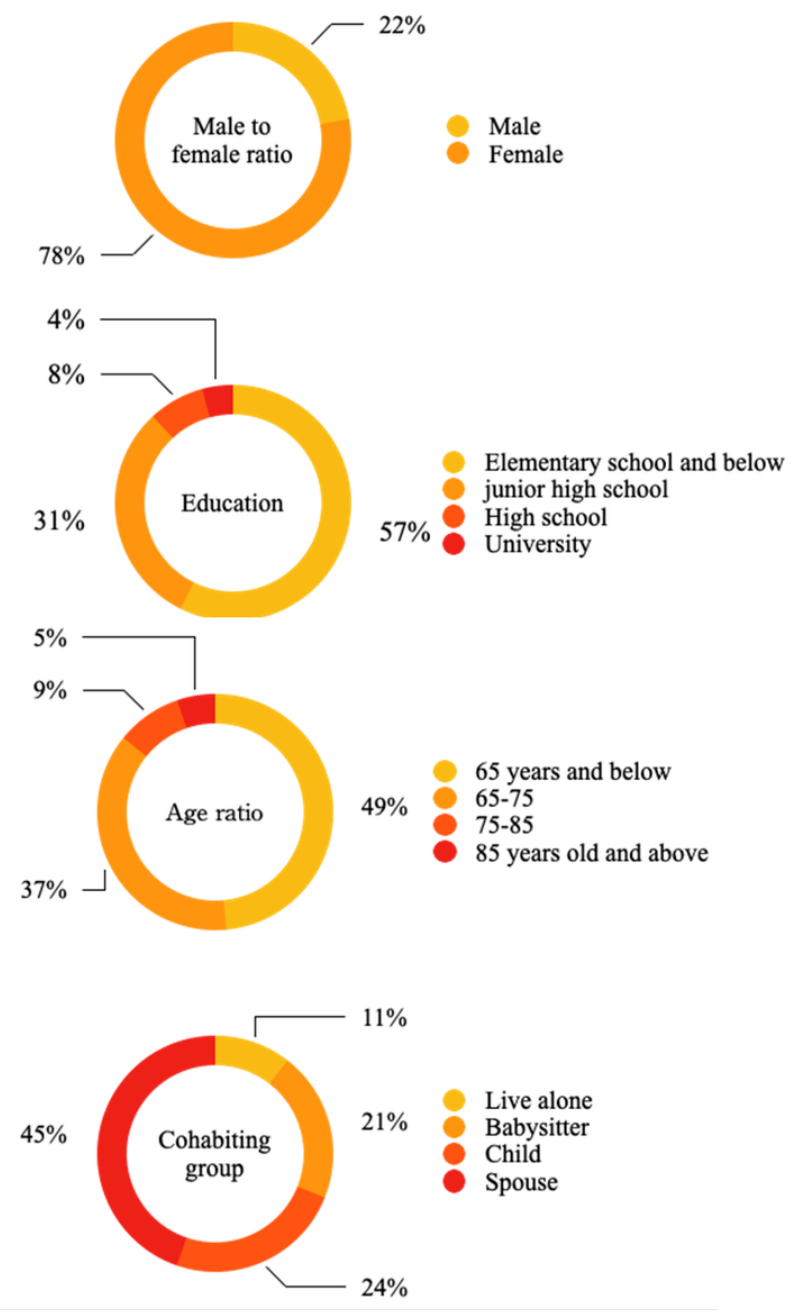

\section{Figure 4}

Basic information of respondents (Source: Self-drawing) 